\title{
Isolation, Identification, In Vitro Antibiotic Resistance and Plant Extract Sensitivity of Fire Blight Causing Erwinia amylovora
}

Mohammed Amirul Islam ${ }^{1 *}$, Md Jahangir Alam¹, Samsed Ahmed Urmee ${ }^{1}$, Muhammed Hamidur Rahaman ${ }^{2}$, Mamudul Hasan Razu² and Reaz Mohammad Mazumdar ${ }^{3}$

${ }^{1}$ Department of Genetic Engineering and Biotechnology, Shahjalal University of Science \& Technology, Sylhet, Bangladesh

${ }^{2}$ Department of Genetic Engineering and Biotechnology, University of Rajshahi, Rajshahi-6205, Bangladesh

${ }^{3}$ BCSIR Laboratories Chittagong, Bangladesh Council of Scientific and Industrial Research, Chittagong-4202, Bangladesh

\begin{abstract}
Background: Erwinia amylovora is the causal organism of fire blight. The fire blight is widely spread in bacterial disease of plants from both epidemiological and economic points of view. Furthermore, the situation is worsening by the advent of increased antibiotic resistance in these bacteria. The study was aimed to determine the in vitro antibiotic and herbal sensitivity of $E$. amylovora isolated from plants available in Sylhet, Bangladesh.

Methods: In this study, bacterial isolates taken from five fire blight infected plants like apple, pear, lemon, orange and olive plants were identified based on morphological, cultural and biochemical characteristics. All the isolates were tested for antibiotic sensitivity against five commonly used antibiotics and herbal sensitivity against five plants extract.

Results: Morphological, physiological and biochemical study of pure culture of suspected organism revealed $E$ amylovora bacteria which was found $100 \%$ resistant to Cefotaxime and $81.89 \%$ to Bacitracin. Chloramphenicol was found most effective as all the isolates were sensitive to it. Besides that, most of the isolates were susceptible to plant extracts and found maximum sensitive to Allium sativum and Syzygium cumini whereas resistant to $V$. amurensis.
\end{abstract}

Conclusion: It can be concluded that the investigation of herbal treatment can be implicated for fire blight disease in contrast of antibiotic test in future.

Keywords: Fire blight; Erwinia amylovora; Antibiotic sensitivity and plant extract

\section{Introduction}

Most damaging disease in the fruit growing world is fire blight caused by Erwinia amylovora (Burrill) [1], a gram negative, facultative anaerobic, rod shaped bacterium belongs to Enterobacteriaceae family (EPPO, 2006) which generally infects plants from the Rosaceae family [1]. It was considered to be native to North America and later detected in New Zealand in 1920 is now present in 43 countries [2]. Although the life cycle of the bacterium is still not well understood, it is known that it can survive as endophyte or epiphyte for variable periods of time depending of environmental factors [3]. The development of fire blight symptoms follows the seasonal growth development of the host plant. It begins in the spring with the production of the primary inoculum and the blossoms infection, continuing on summer with the shoots and fruits infection. Economic importance of this disease is caused losses of 68 million dollars in North-West America, 10 million dollars in one region of New Zealand, and 500,000 trees were destroyed in Lebanon and in Italy [4]. Since the discovery of fire blight in Morocco in May 2006 [5] the disease spread to most of the pome fruit producing regions, inducing severe damage. There is no single control measure for fire blight that will totally eradicate the disease, provide an absolute cure, or fully protect an orchard. However, fire blight damage can be kept to a minimum by using large number of chemicals like copper compounds, antibiotics, carbamates and miscellaneous compounds.. But the main disadvantage of chemicals like copper compounds is their phytotoxicity on host plants, especially pears [6] whereas antibiotics have lead to the selection of resistant bacterial populations and therefore their use is strictly limited or even forbidden in a number of countries [7]. For this reason many researcher trying to establish alternative controlling pathway of the pathogen since 1989 by using plant extract instead of chemical $[8,9]$. Moreover, using of plant extracts is eco-friendly and may reduce cost of cultivation. Considering all these viewpoints, our objective of the research work was to identify the bacteria on the basis of morphological, physiological, biochemical test and make a comparative study in vitro between antibiotic and plant extract sensitivity of the organism.

\section{Materials and Methods}

\section{Collection and processing of samples}

Total number of 21 diseased plant samples was collected from different nurseries of Sylhet city according to standard pathological procedure. Then, $1 \mathrm{ml}$ of fruits rinsed water and fruit juices sample was taken to a test-tube containing $9 \mathrm{ml}$ of sterile water and thoroughly mixed to get a $10^{-1}$ dilution of the water sample. Again, $1 \mathrm{ml}$ of $10^{-1}$ dilution was transferred again to another $9 \mathrm{ml}$ of sterile water in another test-tube and thoroughly mixed to get a $10^{-2}$ dilution. In such way serial dilution of water samples were made up to $10^{-4}$.

*Corresponding author: Mohammed Amirul Islam, Department of Genetic Engineering and Biotechnology, Shahjalal University of Science \& Technology, Sylhet, Bangladesh, Tel: 880-821-713491; amirul.geb@gmail.com

Received: August 03, 2014; Accepted September 27, 2014; Published September 29, 2014

Citation: Islam MA, Alam MD, Urmee SA, Rahaman MH, Razu MH, et al (2014) Isolation, Identification, In Vitro Antibiotic Resistance and Plant Extract Sensitivity of Fire Blight Causing Erwinia amylovora. J Plant Pathol Microb 5: 233. doi:10.4172/2157-7471.1000233

Copyright: @ 2014 Islam MA, et al. This is an open-access article distributed under the terms of the Creative Commons Attribution License, which permits unrestricted use, distribution, and reproduction in any medium, provided the original author and source are credited. 
Citation: Islam MA, Alam MD, Urmee SA, Rahaman MH, Razu MH, et al. (2014) Isolation, Identification, In Vitro Antibiotic Resistance and Plant Extract Sensitivity of Fire Blight Causing Erwinia amylovora. J Plant Pathol Microb 5: 233. doi:10.4172/2157-7471.1000233

Page 2 of 4

\begin{tabular}{|c|c|c|c|}
\hline Scientific name & Local name & Used parts & Used volume( $\boldsymbol{\mu l})$ \\
\hline Allium cepa & Onion & Bulb & 50 \\
\hline Allium sativum & Garlic & Leaf & 50 \\
\hline Syzygium cumini & Kalajam & Leaf & 50 \\
\hline Vitis amurensis & Grape & Leaf \\
\hline Litchi chinensis & Litchi & 50 \\
\hline
\end{tabular}

Table 1: Herb samples used for in vitro herbal sensitivity experiment.

\begin{tabular}{|c|c|c|c|c|c|c|c|c|c|c|c|c|c|c|}
\hline \multirow{2}{*}{ Samples Code } & \multirow{2}{*}{ G } & \multirow{2}{*}{$\begin{array}{l}\text { Growth } \\
\text { at } 39^{\circ} \mathrm{C}\end{array}$} & \multirow{2}{*}{$\begin{array}{l}\text { Growth at } \\
4 \% \mathrm{NaCl}\end{array}$} & \multirow{2}{*}{$\begin{array}{c}\text { FI under } \\
\text { UV }\end{array}$} & \multicolumn{2}{|c|}{ TSI } & \multirow{2}{*}{ I } & \multirow{2}{*}{ C } & \multirow{2}{*}{$\mathbf{N}$} & \multirow{2}{*}{ OF } & \multirow{2}{*}{$\mathbf{U}$} & \multirow{2}{*}{ Gel } & \multirow{2}{*}{$\mathrm{Ma}$} & \multirow{2}{*}{ Su } \\
\hline & & & & & Gas & $\mathrm{H}_{2} \mathrm{~S}$ & & & & & & & & \\
\hline $\mathrm{F} 1$ & Rod - & - & + & - & + & - & - & + & - & $\mathrm{F}$ & - & + & + & + \\
\hline $\mathrm{F} 2$ & Rod - & - & + & - & + & - & - & + & - & $\mathrm{F}$ & - & + & + & + \\
\hline F3 & Rod - & - & + & - & + & - & - & + & - & $\mathrm{F}$ & - & + & + & + \\
\hline $\mathrm{F} 4$ & Rod - & - & + & - & + & - & - & + & - & $\mathrm{F}$ & - & + & + & + \\
\hline F5 & Rod - & - & + & - & + & - & - & + & - & $\mathrm{F}$ & - & + & + & + \\
\hline F6 & Rod - & - & + & - & + & - & - & + & - & $\mathrm{F}$ & - & + & + & + \\
\hline $\mathrm{F} 7$ & Rod - & - & + & - & + & - & - & + & - & $\mathrm{F}$ & - & + & + & + \\
\hline F8 & Rod - & - & + & - & + & - & - & + & - & $F$ & - & + & + & + \\
\hline F9 & Rod - & - & + & - & + & - & - & + & - & $\mathrm{F}$ & - & + & + & + \\
\hline F10 & Rod - & - & + & - & + & - & - & + & - & $\mathrm{F}$ & - & + & + & + \\
\hline F11 & Rod - & - & + & - & + & - & - & + & - & $\mathrm{F}$ & - & + & + & + \\
\hline
\end{tabular}

G = Gram Test, FI= Fluorescent, TSI = Triple Sugar Iron, I= Indole Test, C = Citrate Test, OF = Oxidation Fermentation Test, N= Nitrate Test, U= Urease Test, Gel= Gelatine Liquefaction, Ma= Mannitol Fermentation, Su= Sucrose Fermentation.

Table 2: Physiological \& Biochemical tests for identification of bacterial isolates causing Fire Blight.

\section{Isolation, purification and preservation of the isolates}

Isolation of E. amylovora was done on Nutrient Agar (NA) or Leavan media which was prepared by dissolving $1 \mathrm{~g}$ yeast extract, 2.5 g peptone, $2.5 \mathrm{~g} \mathrm{NaCl}, 25 \mathrm{~g}$ sucrose into $500 \mathrm{ml}$ of distilled water, $\mathrm{pH}$ adjusted to $7.0-7.2$ and sterilized by autoclaving at $121^{\circ} \mathrm{C}, 15$ psi for 15 minutes. Then, transferred the suspected single colony from NA plate by sterile loop and inoculated on the King's medium agar B (KB) which was prepared by peptone $20 \mathrm{~g}$, glycerol $10 \mathrm{~mL}, \mathrm{~K}_{2} \mathrm{HPO}_{4} 1.5 \mathrm{~g}, \mathrm{MgSO}_{4} \cdot 7$ $\mathrm{H}_{2} \mathrm{O} 1.5 \mathrm{~g}$, agar $15 \mathrm{~g}$, distilled water $1000 \mathrm{~mL}, \mathrm{pH}$ adjusted to 7.0-7.2 and sterilized by autoclaving at $121^{\circ}$ for 20 minutes [10]. The plates were then incubated at $27^{\circ} \mathrm{C}$ for 2-3 days and observed daily for bacterial growth. Suspected colonies of E. amylovora (white, circular, mucoid, and curved) were selected and further purified again on KB agar at $27^{\circ} \mathrm{C}$. This operation was repeated three to four times to be sure that pure cultures were obtained for identification tests [11] and preserved it for next investigation.

\section{Identification of the isolates}

For identification of E. amylovora, colony morphology was studied when it appeared in KB and NA media. Moreover, Gram's staining was performed as described by [12] and growth of pure cultured isolates was measured at $39^{\circ} \mathrm{C}$ and $4 \% \mathrm{NaCl}$ containing NA media. Besides that, fluorescent test was done and under UV light at $366 \mathrm{~nm}$ after $48 \mathrm{~h}$ of incubated plate.

\section{Biochemical tests}

Biochemical tests like oxidative-fermentative test, nitrate reduction test, citrate utilization test, urease test, sucrose fermentation test, TSI (Triple Sugar Iodine) test, mannitol fermentation test, gelatine hydrolysis were done.

\section{Antibiotic susceptibility test}

In antibiotic susceptibility test $250 \mu \mathrm{l}$ of microbial inoculums of E. amylovora strain from cultured nutrient broth was spread on the surface of Mueller-Hinton agar (CM337-OXOID) by using a sterile L-shaped glass rod. Then in vitro five different commercially available antimicrobial discs Streptomycin $(10 \mu \mathrm{g})$, Gentamycin $(10 \mu \mathrm{g})$, Chloramphenicol $(30 \mu \mathrm{g})$, Cefotaxime $(5 \mu \mathrm{g})$, Bacitracin $(10 \mu \mathrm{g})$ were applied on the inoculated plates according to the Kirby-Bauer [13] During susceptibility test same bacterial density was maintained by using Spectrophotometer at $\mathrm{OD}_{600}$. After incubation, the plates were examined and the diameters of the zone of complete inhibition were measured in $\mathrm{mm}$.

\section{Plant extracts sensitivity studies}

The antimicrobial activity of five plants extracts were used in the herbal sensitivity experiments. Name and parts of the plants are given in Table 1. After cleaning the selected parts of plant by sterilized distilled water, extracts were collected in a falcon tube and centrifuged at $4000 \mathrm{rpm}$ for few minutes. Besides that wells of $5 \mathrm{~mm}$ diameter were punched into the agar plates with the help of sterilized cork borer and $50 \mu \mathrm{l}$ of the plant extracts were added by using a micropipette to the wells made in the agar plate along with well diffusion $0.1 \mathrm{ml}$ of diluted inoculum of the freshly cultured experimental strains. Inhibitory response of the herbal extracts was recorded according to the normal growth response of the bacteria after incubation at $28^{\circ} \mathrm{C}$ for 24 hour and zone of inhibition was measured by $\mathrm{mm}$.

\section{Results and Discussion}

Fire blight is alarming hazardous threat to citrus fruits and for economy. So, proper understanding of the pathogenic specialization of this pathogen is necessary. Bacteria were isolated from plant samples and identified using cultural, physiological and biochemical test.

\section{Isolation and identification of bacteria}

Morphological studies of $E$. amylovora colonies were done after incubating pure culture at $28^{\circ} \mathrm{C}$ for overnight on NA and $\mathrm{KB}$ media (Table 2 and Figure 1A). Physical appearance of isolates showed whitish, circular, domed, smooth, mucoid colonies on NA media (Figure 1B) 
Citation: Islam MA, Alam MD, Urmee SA, Rahaman MH, Razu MH, et al. (2014) Isolation, Identification, In Vitro Antibiotic Resistance and Plant Extract Sensitivity of Fire Blight Causing Erwinia amylovora. J Plant Pathol Microb 5: 233. doi:10.4172/2157-7471.1000233

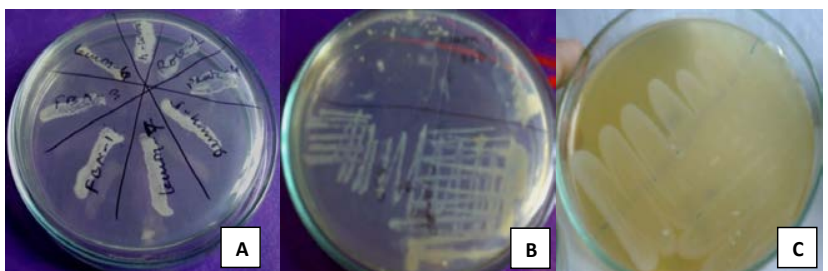

Figure 1: A. Pure culture of Erwinia amylovora from different fire blight infected plant, B. E. amylovora on NAS media and C. E. amylovora on KB media.

\begin{tabular}{|c|c|c|c|c|c|}
\hline \multirow{2}{*}{ Name of Antibiotics } & \multirow{2}{*}{$\begin{array}{c}\text { Disc } \\
\text { Conc. }\end{array}$} & \multirow{2}{*}{$\begin{array}{c}\text { No. of } \\
\text { isolate }\end{array}$} & \multicolumn{3}{|c|}{$\begin{array}{c}\text { Sensitivity pattern of } \\
\text { Erwinia amylovora(11) }\end{array}$} \\
\cline { 4 - 6 } & & & $\% \mathrm{R}$ & $\% \mathrm{l}$ & $\% \mathrm{~S}$ \\
\hline Streptomycin (S) & $10 \mu \mathrm{g}$ & 20 & 18.1 & 27.3 & 54.6 \\
\hline Bacitracin (B) & $10 \mu \mathrm{g}$ & 20 & 81.89 & 18.1 & - \\
\hline Chloramphenicol (C) & $30 \mu \mathrm{g}$ & 20 & - & 18.1 & 81.89 \\
\hline Cefotaxime (CTX) & $30 \mu \mathrm{g}$ & 20 & 100 & - & - \\
\hline Gentamycin (GEN) & $10 \mu \mathrm{g}$ & 20 & 9.99 & 54.6 & 36.4 \\
\hline
\end{tabular}

$\mathrm{R}=$ resistant, $\mathrm{I}=$ intermediate and $\mathrm{S}=$ susceptible

Table 3: Antibiogram of isolated Erwinia amylovora causing Fire Blight.
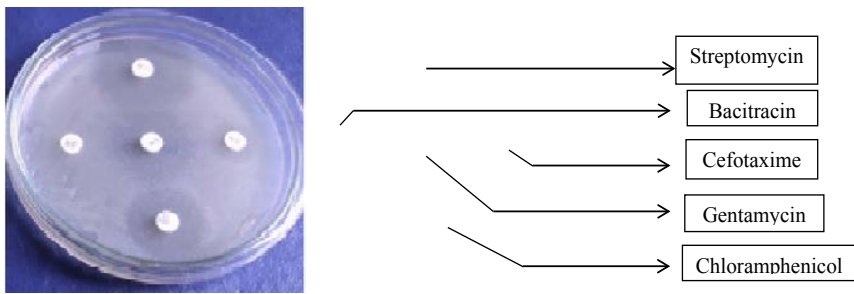

Figure 2: Antibiogram of Erwinia amylovora

\begin{tabular}{|c|c|c|c|c|c|c|c|c|c|c|c|c|}
\hline $\begin{array}{c}\text { Plant } \\
\text { samples }\end{array}$ & F1 & F2 & F3 & F4 & F5 & F6 & F7 & F8 & F9 & F10 & F11 \\
\hline A. sativum & 20 & 15 & 14 & 20 & 40 & 14 & 13 & 5 & 16 & 12 & 11 \\
\hline A. cepa & - & - & - & - & - & 2 & - & - & - & - & - \\
\hline S. cumini & 10 & 2 & 3 & - & 3 & - & - & - & 5 & 5 & - \\
\hline V. amurensis & - & & - & - & - & - & - & - & - & 1 & - \\
\hline L. chinensis & - & - & - & - & - & - & - & - & - & - & - \\
\hline
\end{tabular}

Table 4: Isolates with inhibition zone $(\mathrm{mm})$ for different plant samples.

whereas creamy white, circular, intending to spread colonies was found on KB media (Figure 1C) which resemble with [14] and [15] respectively. Among 21 isolates, a total of 20 were indicated as gram negative rod shaped bacteria whereas no growth was observed at $39^{\circ} \mathrm{C}$ and 12 had growth and 9 isolates didn't grow on $4 \%$ salt concentration. Moreover, E. amylovora exhibited non-fluorescent under UV light at $366 \mathrm{~nm}$ after $48 \mathrm{~h}$ which allowed the distinction from fluorescent Pseudomonads.

\section{Biochemical tests}

For biochemical characterization, a series of tests were performed with the suspected gram negative bacteria and results are given in Table 3. After analyzing the results for all bacterial isolates, it was confirmed that 11 isolates were E. amylovora. Identification was done by morphological, physiological and biochemical tests according to the EPPO standards diagnostic protocol (EPPO/CABI). In this table, TSI positive means both the slant and butt turned into yellow due to bacterial fermentation and produce gas and some produce $\mathrm{H}_{2} \mathrm{~S}$ gas Mannitol and Sucrose fermentation positive means both acid and gas were produced and OF result $F$ means they are fermentative bacteria.

\section{Antibiotic susceptibility test}

Antibiotics were first used to control fire blight in the 1950's and quickly became an important tool for disease management. The sustainability of antibiotics for disease prevention has been threatened by emergence of antibiotic-resistant populations of E. amylovora, which has reduced the efficacy of some of the antibiotics in certain locations. It has been evident that bactericidal bind irreversibly to the bacterial ribosome and blocking the synthesis of proteins to make it inactive whereas mutation in chromosomal gene which encodes the production of ribosomal protein makes resistant [16,17]. In our study eleven isolates were screened for drug resistance profile which indicated the sensitivity pattern against commonly used antibiotics in fire blight (Figure 2). All the isolates offered high degree of resistance against the commonly used antibiotics. By comparing the zone created by the isolates with the standard zone of inhibition we found all isolates were $100 \%$ resistant to a single drug except Chloramphenicol (C) was the most sensitive. Among the antibiotics, resistant E. amylovora isolates were $9.99 \%, 81.89 \%, 18.1 \%, 100 \% 0 \%$ against the antibiotic GEN,B, S, CTX and C (Table 3). So, study among the five antibiotics test low resistance showed in Streptomycin and Gentamycin which is in accordance with victoria et al. [18] and Spitkoin and Alvarado [19]. Besides that, tested pathogen revealed highly resistant against Bacitracin and Cefotaxime antibiotics and same results were also found by Kumar, Singh and Robert et al. [20,21] respectively. Moreover, highly susceptible was showed in Chloramphenicol antibiotics against E. amylovora in this research which is not resemblance with Weixin et al. [22] who concluded that hydrolysis of Chloramphenicol by E. coli conferred resistance.

\section{Plant extracts sensitivity studies}

Plants remain one of the main sources of natural products for new therapies particularly in poor countries, because most of them are cost less, affect a wide range of antibiotic resistant microorganisms, and another reason is there is an erroneous impression that herbal medicines have fewer adverse effects [23]. In present research antibacterial activity of aqueous extracts of all the five plants are presented in Table 4 in which highly significant antibacterial activity was observed in A. sativum and $S$. cumini, respectively against the tested pathogen. Our findings agree with other observations [24] who concluded that antimicrobial activity of allicin from garlic (Allium sativum) exhibit strong activity against $E$. carotovora. Even similar results was also found stated that methanol extract of S. cumini to be more effective on both gram positive and gram negative bacteria, and especially against gram positive bacteria such as Staphylococcus aureus and Enterococcus faecalis.

\section{Conclusion}

It can be concluded that, present study showed all the isolates of $E$. amylovora were resistant to at least one or more of commonly used antibiotics. So, emphasis must be placed on the development of effective bactericides and their proper use with knowledge of the appropriate dosage. On the other hand, herbal sensitivity test has paved the way the viable introduction of plants for the treatment of disease causing microorganism in cheaper cost and eco-friendly way. Therefore, it will be more beneficial to put emphasis on biological control of E. amylovora through plant extracts instead of antibiotics. Moreover, further researches are necessary to find more plant species 
Citation: Islam MA, Alam MD, Urmee SA, Rahaman MH, Razu MH, et al. (2014) Isolation, Identification, In Vitro Antibiotic Resistance and Plant Extract Sensitivity of Fire Blight Causing Erwinia amylovora. J Plant Pathol Microb 5: 233. doi:10.4172/2157-7471.1000233

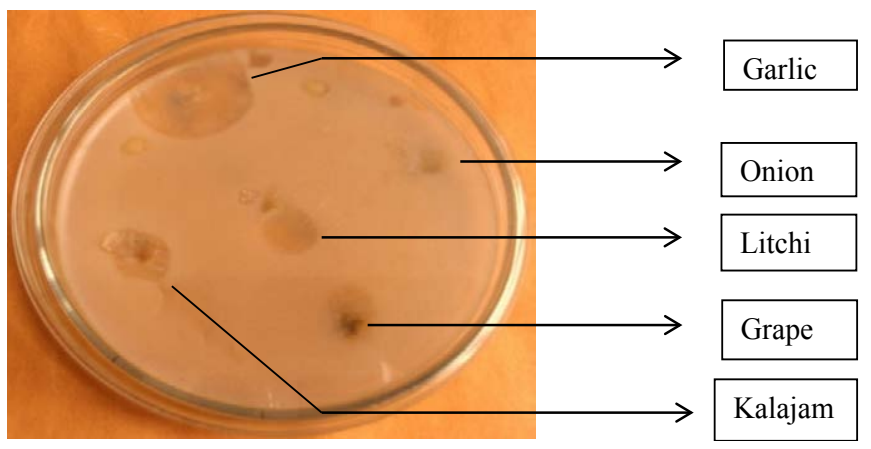

Figure 3: Antimicrobial activity of some plant species on Erwinia amylovora.

and purify the antimicrobial substances present in the crude plant extracts effective against E. amylovora (Figure 3).

\section{References}

1. Ordax M, Marco-Noales E, López MM, Biosca EG (2006) Survival strategy of Erwinia amylovora against copper: induction of the viable-but-nonculturable state. Appl Environ Microbiol 72: 3482-3488

2. Van der Zwet T (2002) Present worldwide distribution of fire blight. Acta Horticulturae (ISHS). 590: 33-34.

3. Thomson SV (2000) Integrated orchard and nursery management for the control of fire blight. In: Fire blight the disease and its causative agent, Erwinia amylovora [ed. by Vanneste JL] Wallingford, UK: CABI 9-36.

4. Vanneste JL (2000) What is fi re blight? Who is Erwinia amylovora How to control it? In: Fire blight: the disease and its causative agent Erwinia amylovora. (Vanneste J.L., edn.). CABI publishing, Wallingford, UK 1-6

5. Fatmi M, Bougsiba M, Saoud H (2008) First report of fire blight caused by Erwinia amylovora on pear, apple and quince in Morocco. Plant Disease 92: 314

6. MÄfruÅ£escu L, Saviuc C, Oprea E, Savu B, Bucur M, et al. (2009) In vitro susceptibility of Erwinia amylovora (Burrill) Winslow et. al. to Citrus maxima essential oil. Roum Arch Microbiol Immunol 68: 223-227.

7. Cesbron S, Thomson SV, Paulin JP (2000) Acibenzolar-S-methyl induces the accumulation of defense-related enzymes in apple and protects from fire blight. European Journal of Plant Pathology 106: 529-536.

8. Mosch J, Mende A, Zeller W, Rieck M, Ullrich W (1993). Plant extracts with a resistance induction effect against fire blight (Erwinia amylovora). Acta Horticulturae 338: 389-395.

9. Mosch J, Zeller W, Rieck M, Ullrich W (1996) Further studies on plant extracts with a resistance induction effect against Erwinia amylovora. Acta Horticulturae 411: 361-366.
10. KING EO, WARD MK, RANEY DE (1954) Two simple media for the demonstration of pyocyanin and fluorescin. J Lab Clin Med 44: 301-307

11. Jones AL, Geider K (2001) Erwinia amylovora group. In: Laboratory guide for identification of plant pathogenic bacteria. 3rd ed. (Schad N. W., Jones J.B. and Chun W., ed.). APS press, St. Paul, MN, USA, 40-54.

12. Merchant IA, Packer RA (1967) Veterinary Bacteriology and Virology. 7th edn., The lowa University Press, Ames, lowa, USA. pp. 286-306

13. Bauer AW, Kirby WM, Sherris JC, Turck M (1966) Antibiotic susceptibility testing by a standardized single disk method. Am J Clin Pathol 45: 493-496.

14. Billing E, Baker LAE, Crosse JE, Garret CME (1961) Characteristics of English isolates of Erwinia amylovora (Burrill) Winslow et al. J. Appl. Bacteriol 24: 195211.

15. Paulin JP, Samson R (1973) Fire blight in France. II. Characters strains Erwinia amylovora (Burrill) Winslow et al. 1920 isolated household Franco-Belge. Annals of Phytopathology 5: 389-397

16. Chiou CS, Jones AL (1995) Expression and identification of the strA-strB gene pair from streptomycin-resistant Erwinia amylovora. Gene 152: 47-51.

17. Jones AL, Schnabel EL (2000) The development of streptomycin-resistant strains of Erwinia amylovora. In Fire blight: the disease and its causative agent, Erwinia amylovora (J. Vanneste, ed.). CAB International, Wallingford, UK pp.235-251.

18. Victoria Donat, Elena G Biosca, Arantza Rico, Javier Penalver, Marisa Borruel, Dionisio Berra, Txaran Basterretxea, Jesus Murillo, Maria M Lopez (2004) Erwinia amylovora strains from outbreaks of fire blight in Spain: phenotypic characteristics(Abstr.). Annals of Applied Biology, 146:105-114. DOI: 10.1111/j.1744-7348.2005.04079.x

19. Spitko RA, Alvarado M (1999) Use of Agry-Gent (Gentamicin sulfate) as control material for fire blight of apple in the U.S. Acta Hort. (ISHS) 489: 629630.

20. Sujeet Kumar, Bhoj Raj Singh (2013) An overview of mechanisms and emergence of antimicrobials drug resistance. Advances in Animal and Veterinary Sciences 1: 7-14.

21. Bonomo RA, Donskey CJ, Blumer JL, Hujer AM, Hoyenm CK, et al. (2003) Cefotaxime-resistant bacteria colonizing older people admitted to an acute care hospital. J Am Geriatr Soc 51: 519-522.

22. Tao W, Lee MH, Wu J, Kim NH, Kim JC, et al. (2012) Inactivation of chloramphenicol and florfenicol by a novel chloramphenicol hydrolase. Appl Environ Microbiol 78: 6295-6301.

23. Ozoula IR, Idogun SE, Tafamel GE (2010) Acute and sub-acute toxicologica assessment of aqueous leaf extract of Bryophyllum pinnatum (Lam) in SpragueDawley rats. Am J. Pharmacol Toxical 5: 145-151.

24. Curtis H, Noll U, Stormann J, Slusarenko A (2004) Broad-spectrum activity of the volatile phyto anti cipinallicin in extracts of garlic (L.) against plan pathogenic bacteria, fungi and Oomycetes. Physiol. Mol. Plant Pathol 65: 7989. 